\title{
Promising deposits of complex iron ore raw materials of Urals and its processing new technologies
}

\author{
Sergei Kornilkov ${ }^{1 *}$, Andrei Dmitriev ${ }^{2}$ and Aleksei Pelevin ${ }^{3}$ \\ ${ }^{1}$ Federal State Budgetary Institution of Science Institute of Mining of Ural branch of RAS, \\ Yekaterinburg, Russia \\ ${ }^{2}$ Federal State Budgetary Institution of Science Institute of Metallurgy of Ural branch of RAS, \\ Yekaterinburg, Russia \\ ${ }^{3}$ Federal State Budgetary Educational Institution for Higher Education Ural State Mining University, \\ Yekateriburg, Russia
}

\begin{abstract}
Annotation. There have been provided general geological and metallurgical characteristics of some complex iron ore raw materials of Urals, which contain not only iron but also titanium, vanadium, chrome, and nickel. There has been provided the description of such deposits. It is shown that the degree of extraction of certain products is determined by the choice of extraction, benefication, pyrometallurgical processing procedures.
\end{abstract}

\section{Introduction}

In general iron-bearing ores of the Ural region are the complex ones, and the fuller extraction of associated components from them is an important reserve for increasing production of not only iron but also of non-ferrous, precious metals and rare elements at all stages of their processing. In connection with that the aim of developing new and improving existing benefication methods and processing procedure at metallurgical enterprises appears, because the complex ore processing leads to production prime cost reduction, providing a significant ores saving.

Among Urals complex deposits are titanium-containing ores (Kachkanarskoye, Kopanskoye, Medvedevskoye deposits) and brown chrome ores of Serov deposit, which contain chrome and nickel, besides iron. Titanium-containing sands of Yaregskoye deposit oil-containing sandstones of the Komi Republic also bear mentioning, it contains about the half of titanium dioxide reserves of Russia. The equivalent Athabaska oil sands deposit is situated in Canada. Titanium isn't developed in both these deposits because of the absence of an effective technology.

Having regard to the above, the aim of the research is the mining and technological justification of the mining and metallurgical complex raw materials extension (ilmenite titanium magnetite ores), obtained in virtue of the observation of concentration properties

* Corresponding author: kornilkov@igduran.ru 
and technologies of their complete metallurgical processing with pyrometallurgical methods at the complex extraction of iron, titanium and vanadium, including:

- the evaluation of mineral resources base of titanium-containing ores of the Nothern and Southern Urals;

- the evaluation of the ilmenite titanium magnetite ores pyrometallurgical processing availability;

- the development of titanium-containing ores, titanium-containing sands and brown chrome ores processing procedure.

\section{General characteristics of complex ores deposits}

Russia possesses large balance reserves of titanium dioxide, which exceed 500 million tons and takes the fourth place in the world after Ukraine, China and Australia. In connection with the reunion of Crimea and Russia the loading of Crimea's Titan, pigmental dioxide production plant in Armyansk with the capacity of 120000 tones a year, which works with Ukrainian raw materials, is of interest.

The half of titanium reserves of Russia is enclosed in magmatic type deposits, which contain iron and vanadium, besides titanium. At the present time only the ores of Kachkanar deposits group $\left(16.2 \% \mathrm{Fe}, 0.13 \% \mathrm{~V}_{2} \mathrm{O}_{5}, 1.23 \% \mathrm{TiO}_{2}\right)$ are processed, and only iron and vanadium are extracted by the blast furnace - converter procedure.

Titanium-containing ores of the deposits like Medvedevskoye and Kopanskoye ones are generally considered as a source of iron, and, possibly, of vanadium. Still these ores can be considered as a source of titanium and pigmental titanium dioxide. Moreover, pigmental titanium dioxide hasn't been developed in Russia for 25 years.

It's important to notice, that in Urals and in Eastern regions the iron-ore basis of ferrous metallurgy of Russia is mostly represented by the ores of a similar type: Kopanskoye, Chineyskoye, Kruchininskoye, Kuranakhskoye, Bolshoy Seyim deposits, which contain more than $30 \%$ of titanium reserves of Russia.

Brown chrome ores Serov deposit is represented by complex raw materials $\left(\mathrm{Fe}_{\mathrm{gen}}=36-\right.$ $38 \%, \mathrm{Ni}-0.18-0.39 \%, \mathrm{Cr}_{2} \mathrm{O}_{3}-2.5-3.0 \%$ ), which can be used rationally only if their processing technology foresees the most complete extraction of all alloying components and metallurgical extraction products utilization. In that respect the usage of the virgin charge is preferential for naturally alloyed chromium-nickel steel production (up to 50 grades according to Uralgipromez evaluation), and also for the high quality prefabrication for Ural semi-integrated plants. Serov ores are clean by sulfur and phosphorus, they almost don't contain cooper, and attract attention because of scrap materials, which are the source of unfavorable admixtures in the steel-melting process.

The general metallurgical characteristics of the above-mentioned deposits is provided in the work [1].

\section{Technologies of separate excavation and benefication}

The results of beneficiation of samples of the Gusevogorsky deposit ore mineral types showed, that ore with low concentration of titanium has a better beneficiation ability, than ore with normal concentration of titanium has. It has been determined that it is rational to divide ore with low concentration of titanium and ore with normal concentration of titanium to different technological types and process them separately because of differences in beneficiation ability and grindability. Herewith the accumulated technological and economical indexes of the separate beneficiation of ore natural types may be higher than bulk mining ore beneficiation indexes [9]. 
Table 1. Characteristics of titanium raw materials processing technologies

\begin{tabular}{|c|c|c|c|c|}
\hline \multirow{2}{*}{$\begin{array}{l}\text { Beneficiation } \\
\text { plant, object }\end{array}$} & \multirow{2}{*}{$\begin{array}{l}\text { Beneficiation } \\
\text { procedure }\end{array}$} & \multicolumn{2}{|c|}{$\begin{array}{l}\text { Content in } \\
\text { concentration }\end{array}$} & \multirow{2}{*}{$\begin{array}{l}\text { Processed raw } \\
\text { materials }\end{array}$} \\
\hline & & $\mathrm{Fe}, \%$ & $\mathrm{TiO}_{2}, \%$ & \\
\hline \multicolumn{5}{|c|}{ Ore deposits } \\
\hline Kusinskaya & $\begin{array}{c}\text { Magnetic } \\
\text { gravitational flotation }\end{array}$ & 60 & $\begin{array}{c}45 \\
\text { (up to 48) }\end{array}$ & bucked ore \\
\hline Olekminskaya & $\begin{array}{c}\text { Magnetic } \\
\text { highly magnetic } \\
\text { electrical }\end{array}$ & 62 & 48 & bucked ore \\
\hline \multirow{2}{*}{$\begin{array}{c}\text { Bolshoy Seyim } \\
\text { deposit }\end{array}$} & $\begin{array}{c}\text { Magnetic } \\
\text { highly magnetic } \\
\text { electrical }\end{array}$ & - & 46,5 & $\begin{array}{l}\text { rough ilmenite } \\
\text { concentrate }\end{array}$ \\
\hline & $\begin{array}{c}\text { Magnetic } \\
\text { higly magnetic } \\
\text { electrical }\end{array}$ & - & 50,67 & $\begin{array}{l}\text { rough ilmenite } \\
\text { concentrate }\end{array}$ \\
\hline \multirow{3}{*}{$\begin{array}{c}\text { Kopanskoye } \\
\text { deposit }\end{array}$} & $\begin{array}{c}\text { Magnetic } \\
\text { gravitational }\end{array}$ & 24,4 & 44,3 & $\begin{array}{l}\text { ilmenite titanium } \\
\text { magnetite ore }\end{array}$ \\
\hline & $\begin{array}{l}\text { Magnetic } \\
\text { flotation }\end{array}$ & 13,8 & 45,2 & $\begin{array}{l}\text { titanium magnetite } \\
\text { ilmenite ore }\end{array}$ \\
\hline & $\begin{array}{c}\text { Magnetic } \\
\text { highly magnetic } \\
\text { electrical }\end{array}$ & 19,2 & 50,6 & ilmenite ore \\
\hline \multirow{3}{*}{$\begin{array}{c}\text { Medvedevskoye } \\
\text { deposit }\end{array}$} & $\begin{array}{l}\text { Magnetic } \\
\text { flotation }\end{array}$ & \multirow{2}{*}{$60-63$} & \multirow{2}{*}{$4-6$} & $\begin{array}{c}\text { ilmenite titanium } \\
\text { magnetire ore }\end{array}$ \\
\hline & $\begin{array}{c}\text { Magnetic } \\
\text { gravitational }\end{array}$ & & & $\begin{array}{l}\text { titanium magnetite } \\
\text { ilmenite ore }\end{array}$ \\
\hline & $\begin{array}{l}\text { Magnetic } \\
\text { electrical }\end{array}$ & - & $45-48$ & ilmenite ore \\
\hline \multicolumn{5}{|c|}{ Alluvial deposits } \\
\hline $\begin{array}{c}\text { Novopokrovskoy } \\
\text { e } \\
\text { «Steklyanka» }\end{array}$ & $\begin{array}{l}\text { Gravitational } \\
\text { electrical } \\
\text { magnetic }\end{array}$ & - & $45-47$ & $\begin{array}{l}\text { bare titanium zircon } \\
\text { sands }\end{array}$ \\
\hline Tarskoye & $\begin{array}{l}\text { Gravitational } \\
\text { electrical } \\
\text { magnetic }\end{array}$ & - & 54,2 & $\begin{array}{l}\text { bare titanium zircon } \\
\text { sands }\end{array}$ \\
\hline Butkinskoye & $\begin{array}{l}\text { Magnetic } \\
\text { electrical }\end{array}$ & - & 48 & $\begin{array}{l}\text { bare titanium zircon } \\
\text { sands }\end{array}$ \\
\hline \multicolumn{5}{|c|}{ Man-made mineral formations } \\
\hline Gusevogorskoye & $\begin{array}{l}\text { Magnetic } \\
\text { gravitational }\end{array}$ & - & 40,1 & $\begin{array}{c}\text { tailings of the Wet } \\
\text { Magnetic Separation- } \\
\text { I,II,III }\end{array}$ \\
\hline Volkovskoye & $\begin{array}{c}\text { Magnetic } \\
\text { gravitational }\end{array}$ & - & 41,25 & $\begin{array}{l}\text { tailings of titanium } \\
\text { magnetite flotation }\end{array}$ \\
\hline Kusinskoye & $\begin{array}{l}\text { Magnetic } \\
\text { electrical }\end{array}$ & 36,8 & 53 & mature tailings \\
\hline $\begin{array}{l}\text { Gold deposits } \\
\text { barrows }\end{array}$ & Magnetic & - & 44 & mature tailings \\
\hline
\end{tabular}


The following issues have been discussed at bringing grounds for the re-engineering of titanium-containing deposits with separate iron and titanium, iron and vanadium ore types:

-Substantiation of factors, which effect on ore natural types separation;

-Improvement of excavation and ore preparation technological procedures at forming separate flows of titanium-containing iron ore raw materials.

- Development of the geoinformational data processing procedure at geometrization of ilmenite titanium and manganese ores natural types.

The performed classification of titanium-containing raw materials (Table 1), from which titanium concentrates are received for the further processing, showed, that the following may be a raw materials base:

1. ore deposits (ilmenite titanium magnetite, titanium magnetite ilmenite, ilmenite);

2. alluvial deposits (titanium and zircon deposits);

3. man-made mineral formations (titanium magnetite ores processing tailing, goldcontaining deposits beneficiation tailings);

4. titanium magnetite concentrates melting slag.

The data from Table 1 certifies that titanium concentrates, produced by different technological procedures, but the technologies of production of titanium from slag have been studied least of all, although they are promising from the point of view of the mineral wealth complex usage.

The evaluation of concentrates magnetic properties, performed at the Institute of Metallurgy of Ural branch of RAS showed that titanium magnetite of the type of ore with low concentration of titanium is less hard-magnetic than titanium magnetite of the type of ore with normal concentration of titanium. Coercitive force is 82 against 93 Oe $(0.0083$ against $0.0093 \mathrm{~T}$ ).

It lets us to tell that the efficiency of classification in hydraulic cyclones and the efficiency of beneficiation in drum magnetic separators for wet beneficiation would be higher at the beneficiation of ore with low concentration of titanium.

Lesser magnetic hardness of titanium magnetite in ore with low concentration of titanium of Gusevogorskoye deposit is one of the factors, which encourages the reception of concentrate with larger content of iron of this type and a specific reduction of energy consumption necessary for its receipt.

According to the data of detailed and operational reconnaissance with the help of GIS software it has been performed geometrization of ores quality specifications in terms of excavated open-cuts (Northern, Main, and Western open-cuts). There have been determined zones with different concentration of valuable components $(\mathrm{Fe}, \mathrm{Ti}, \mathrm{V})$. It has been shown that the distribution of vanadium in ores depends on magnetite quantity in ores. It has been developed a prototype of the Cloud data base with restriction on viewing specific sections and editing.

Preliminary calculations show that the minimum content of $\mathrm{TiO}_{2}$ in concentrate shall be less than $7 \%$ in order that the titanium dioxide content would be acceptable for the further processing. These conditions may be implemented due to the separate development of the Gusevogorskoye deposit part with high content of titanium, and, particularly, Kachkanar titanium magnetite deposit.

Such approach may be used at Medvedevskoye and Kopanskoye deposits operation. The Institute of Metallurgy of Ural branch of RAS has shown that Medvedevskoye and Kopanskoye deposits concentrates may serve as raw materials for high quality pigmented titanium dioxide production [8]. 


\section{New pyrometallurgical technologies}

New suggested technologies of excavation and beneficiation of Gusevogorskoye deposit titanium magnetite ores with getting iron-ore concentrates with low and high content of titanium [2,3] let to offer new pyrometallurgical technologies of these concentrates processing according to the blast furnace - converter procedure and metalling - electric smelting procedure [4].

There have been studied two laboratory samples of acidified iron-ore pellets, obtained from Gusevogorskoye deposit concentrates with high and low content of titanium. The recovery grade (recoverability according to GOST 23581.11-79) is provided in Table 2.

Table 2. Pellets recoverability

\begin{tabular}{|l|c|}
\hline Sample & Pellets recoverability, unit fraction \\
\hline High content of titanium & 0.75 \\
\hline Low content of titanium & 0.98 \\
\hline
\end{tabular}

The result of the research of acidified pellets strength after the low-temperature recovery according to GOST 13930 are provided in Table 3.

Table 3. Pellets strength, $\%$

\begin{tabular}{|l|c|c|}
\hline Index & $\begin{array}{l}\text { Sample with high } \\
\text { content of titanium }\end{array}$ & $\begin{array}{l}\text { Sample with low content of } \\
\text { titanium }\end{array}$ \\
\hline LTD $_{+6,3}$ & 65.71 & 69.92 \\
\hline LTD $_{-3,15}$ & 12.87 & 11.39 \\
\hline LTD $_{-0,5}$ & 2.17 & 1.67 \\
\hline
\end{tabular}

The result of the research of acidified pellets softening temperature interval according to GOST 17212-84 are provided in Table 4.

Table 4. Pellets softening temperature interval

\begin{tabular}{|c|c|c|}
\hline Index & $\begin{array}{c}\text { Sample with high content of } \\
\text { titanium }\end{array}$ & $\begin{array}{c}\text { Sample with low content of } \\
\text { titanium }\end{array}$ \\
\hline $\begin{array}{l}\text { Temperature of } \\
\text { softening starting, }{ }^{\circ} \mathrm{C}\end{array}$ & 1210 & 1180 \\
\hline $\begin{array}{l}\text { Temperature of } \\
\text { softening ending, }{ }^{\circ} \mathrm{C}\end{array}$ & 1300 & 1310 \\
\hline
\end{tabular}

Estimate indexes of blast-furnace smelting of acidified pellets with high content of titanium are provided in Table 5. The calculations have been performed with the help of math model [5]. The content of $\mathrm{TiO}_{2}$ in slag amounts to $14.82 \%$, which shall not cause problems at the blast-furnace operation.

In Table 6 estimate indexes of metallized pellets with high content of titanium in ore thermal furnace are provided. The calculations are performed with the help of math model [6]. The examination of rationality of processing of concentrate with high content of titanium according to the metalling - electrical smelting procedure certify, that metallized pellets with the content of general iron $-79.79 \%, \mathrm{TiO}_{2}-4.21 \%$ and $\mathrm{V}_{2} \mathrm{O}_{5}-0.86 \%$ can be obtained from the received material. It is shown that their smelting will lead to the formation of slag, containing $\mathrm{TiO}_{2}(22.88 \%)$, insufficient for economical receipt of pigment titanium dioxide or titanium sponge from it. 
Table 5. Estimate indexes of pellets blast-furnace smelting

\begin{tabular}{|l|l|}
\hline Cast iron content, $\%$ & Slag content, \% \\
$\mathrm{Ti}-0.15$ & $\mathrm{CaO}-28.9$ \\
$\mathrm{C}-4.67$ & $\mathrm{SiO}-23.7$ \\
$\mathrm{Fe}-94.38$ & $\mathrm{Al}_{2} \mathrm{O}_{3}-17.07$ \\
$\mathrm{~V}-0.54$ & $\mathrm{FeO}-0.61$ \\
$\mathrm{Mn}-0.13$ & $\mathrm{~V}_{2} \mathrm{O}_{5}-0.33$ \\
$\mathrm{Si}-0.07$ & $\mathbf{T i O}_{\mathbf{2}}-\mathbf{1 4 . 8 2}$ \\
\hline Blast-furnace volume $-2200 \mathrm{~m}^{3}$ \\
Productive capacity $-7210 \mathrm{t}$ of cast iron a day \\
Coke consumption $-322.5 \mathrm{~kg} / \mathrm{t}$ of cast iron \\
\hline
\end{tabular}

Table 6. Indexes of metallized pellets smelting

\begin{tabular}{|l|l|}
\hline Metal composition, \% & Slag composition, \% \\
$\mathrm{Ti}-0.05$ & $\mathrm{CaO}-9.64$ \\
$\mathrm{C}-2.50$ & $\mathrm{SiO}_{2}-21.20$ \\
$\mathrm{Fe}-96.21$ & $\mathrm{Al}_{2} \mathrm{O}_{3}-22.41$ \\
$\mathrm{~V}-0.484$ & $\mathrm{FeO}-7.50$ \\
$\mathrm{P}-0.03$ & $\mathrm{~V}_{2} \mathrm{O}_{5}-0.90$ \\
$\mathrm{Si}-0.7$ & $\mathbf{T i O}_{\mathbf{2}}-\mathbf{2 2 . 8 8}$ \\
\hline Capacity of thermal furnace $-33 \mathrm{MVA}$ \\
Productive capacity $-563.7 \mathrm{t}$ of metal a day \\
Energy consumption $-1011.5 \mathrm{~kW} \cdot \mathrm{h} / \mathrm{t}$ of metal \\
\hline
\end{tabular}

Serov brown chrome ores' particularity is a big amount of alumina contained in it. One of the proposed methods of reducing $\mathrm{Al}_{2} \mathrm{O}_{3} / \mathrm{SiO}_{2}$ in blast-furnace slag is to melt brown chrome ores in the blast-furnace together with silicate nickel ores or other ores. It will allow to get tradable cast iron, containing chrome and nickel, and subsequently to smelt alloy steel from it [7].

By complex researches of technologies for beneficiation and development with ores natural types separation and of advanced metallurgical processing of mineral and manmade raw materials it has been determined that also in Urals it is being created a new mining and metallurgical complex raw materials base not only for the iron production, but also for titanium raw materials production with iron, titanium and vanadium separation by means of pyrometallurgical methods for the organization of titanium magnetite concentrate processing by metalling - electric smelting procedure with the further utilization of slag, containing high amount of titanium.

Primary deposits direct processing with ilmenite and rutile concentrates obtainment may be recognized as a prospective type of titanium raw materials production technology.

The work has been performed with financial support from the Ural branch of RAS Program, project No. 18-5-2345-56.

\section{References}

1. L.I. Leontyev, N.A. Vatolin, S.V. Shavrin, N.S. Shumakov. Pyrometallurgical processing of complex ores. - Moscow: Metallurgy. 432 p. (1997).

2. S.V. Kornilkov, A.N. Dmitriev, A.E. Pelevin, A.M. Yakovlev. Mining magazine. 5. P 86-90. (2016). 
3. A.N. Dmitriev, G.Yu. Vitkina, R.V. Petukhov, S.V. Kornilkov, A.E. Pelevin, A.Y. Fishman, T.V. Sapozhnikova, K. Y. Shunyaev. Advanced Materials Research. 834 - 836. P. 364-369. (2014).

4. A.N. Dmitriev, R.V. Petukhov, G.Yu. Vitkina, Yu.A. Chesnokov, S.V. Kornilkov, A.E. Pelevin. Defect and Diffusion Forum (Diffusion in Solids and Liquids XI). 369. P. 611. (2016).

5. A.V. Chentsov, Yu.A. Chesnokov, S.V. Shavrin. Logic-statistic balance model of blast furnace smelting process. Ural Branch of Russian Academy of Sciences, Ekaterinburg, Russia (2003).

6. A.N. Dmitriev, G.Yu. Vitkina, Yu.A. Chesnokov. Use of Information System "Interactive Calculations in Ferrous Metallurgy", Proceedings of 2014 - Sustainable Industrial Processing Summit/Shechtman International Symposium. June 29 - July 04, 2014. Non-Ferrous, Iron and Steel. 3. (2014).

7. Yu.A. Chesnokov, A.N. Dmitriev, Z.N. Pastukhova, V.P. Perepechaev. Collected works of the All-Russian Conference "Researches in the field of man-made formations and wastes processing and utilization" with the elements of the school for young scientists. 2427.11.2009. Pages 427-432. (2009).

8. Andrey Dmitriev and Leopold Leontiev. Journal of Materials Science and Engineering B 7 (11-12) P. 268-271. (2017).

9. S.V. Kornilkov, A.V. Glebov, A.E. Pelevin, A.N. Dmitriev. Titan. 4. P 8-11. (2017). 